\title{
RESTENOSIS IN THE REMOTE PERIOD AFTER CORONARY STENTING AS REFLECTION OF NEOATHEROSCLEROSIS AND BLOOD LIPIDS
}

\author{
Komkov A.A. ${ }^{1,2,3}$, MazaevV.P. ${ }^{1}$, Ryazanova S.V. ${ }^{1}$, Bazaeva E.V. ${ }^{1}$ \\ ${ }^{I}$ FSI «National Research Centre for Preventive Medicine» of the Ministry of Healthcare of Russian Federation. \\ Moscow, e-mail: vpmazaev@gnicpm.ru; \\ ${ }^{2}$ Public health agency of the city of Moscow «City Clinical Hospital № 67 of Moscow Health Department», Moscow, e- \\ mail: artemkomkov@gmail.com; \\ ${ }^{3}$ FSI «SIC them THAT. N. N. Priorov» of Minzdrav of Russia, Moscow
}

Aims.

The aim of this study was to compare the lipid parameters in patients in the remote period after percutaneous coronary interventions (PCI) provided clinical deterioration in groups with and without restenosis in stents as a manifestation neoatherosclerosis.

Materials and methods.

Clinical and angiographic data and blood lipids were compared in 34 patients without restenosis (group 1) and in 32 patients with restenosis (group 2) in the remote period after PCI (Me632[380;904] days). Based on the source data, the groups were comparable in most clinical parameters, but there was a higher incidence of unstable angina in the group with subsequent restenosis than in the group without it $(p=0.05)$. By angiographic data, the groups were comparable except for more frequent use of coated stents in the group without restenosis $(p=0.025)$.

Results.

During follow-up ("index-PCI - "follow-up coronary angiography (CAG)/PCI"), the mean values of all parameters of the lipid panel and triglycerides (TG) decreased in the groups. The intergroup comparison at follow-up CAG/PCI showed the following: total cholesterol level was higher in group 1 (Me4.7[4.3;5.7]) than in group 2 (Me4.5[3.9;5.0]) ( $p=0.051)$, high-density lipoprotein cholesterol was significantly higher in group 1 than in group 2 (Me3.6[3.1;4.7] and Me3.3[2.8;3.8], respectively, $p=0.033)$. There was no difference between groups in achieving the target level of low-density lipoprotein cholesterol (LDL-C) $(<1.8 \mathrm{mmol} / \mathrm{L})$, and values $<1.5 \mathrm{mmol} / \mathrm{L}$ were extremely rare. In all groups, regardless of the follow-up time and the presence of in-stent restenosis, LDL$\mathrm{C}>2.6 \mathrm{mmol} / \mathrm{L}$ prevailed. In the remote period after PCI, blood lipids did not reach the target level, and their values were worse in the group without restenosis than in the group with restenosis.

Conclusions.

The course of natural atherosclerosis remains the dominant factor of clinical deterioration in the remote period after coronary stenting.

Keywords: lipids, lipid panel, neoatherosclerosis, restenosis, stent, percutaneous coronary intervention

INTRODUCTION. Late restenosis with clinical complications after percutaneous coronary interventions (PCI) with stents is becoming a more significant issue $[1,2]$.

Intravascular alterations in patients with myocardial infarction in the remote period after PCI provided grounds for their classification into a special group of alterations in the stented coronary arteries called neoatherosclerosis [3]. Later restenoses in stents differ from early restenosis caused by fibromuscular proliferation. By structural peculiarities, they have a lot in common with native (natural) atherosclerosis [4]. The study was aimed to compare lipid parameters in the remote period in two groups of patients after PCI: with and without restenosis in stents.

MATERIALS AND METHODS. The analysis included primary and angiographic data and blood lipid parameters of 66 patients with ischemic heart disease that underwent angioplasty and stenting and further repeated coronarography (CAG) for the observed clinical worsening more than 9 months after the primary intervention (median (Me) of the observation period Me 632 [380;904] days).

During the period of observation, patients received pharmacotherapy that included 
antiplatelet therapy, statins, inhibitors of the angiotensin-converting enzyme, and antianginal therapy. Patients received written recommendations on the factors of cardiovascular risk. Repeated hospitalization and examination were performed by the clinical indications: acute coronary syndrome (ACS), angina or other clinical manifestations that required specific diagnostics in inpatient conditions. Patients underwent CAG and repeated PCI when it was necessary.

The study was approved by the ethical committee and all patients signed the form of informed consent.

Patients were divided into two groups depending on the absence (Group I) and presence (Group II) of restenosis in the stent revealed during the repeated CAG.

Clinical and angiographic parameters, cardiovascular risk in the initial condition (index PCI) and after the repeated observation ("follow-up CAG/PCI") included age, sex, angina, acute myocardial infarction (MI), ACS, Chronic kidney disease (CKD), arterial hypertension, dyslipidemia, type 2 diabetes mellitus, smoking, physical inactivity, obesity and body mass index (BMI), alcohol abuse, family anamnesis of cardiovascular disease, weight, drug-eluting stent (DES), and bare-metal stent (BMS).

The analysis of blood for lipids was performed in plasma and serum obtained from the venous blood taken 12 hours after the meal. The analyzer Konelab 20i with Human kits was used for the evaluation of the following parameters: cholesterol of high-density lipoproteins (HDL-C), triglycerides (TG), and total cholesterol (TCH). Friedewald formula was used to calculate the cholesterol of low-density lipoproteins (LDL-C). Non-LDL cholesterol was obtained by the difference between TCH and LDL-C.

\section{Statistical analysis.}

The obtained data were recorded in Excel tables (Microsoft, USA) and further statistical analysis was performed in SPSS Statistics v23 (IBM, USA). In cases of the normal distribution of the quantitative data, the description was presented as the mean and mean square deviation. The quantitative parameters with high asymmetry were presented as the median $(\mathrm{Me}), 25^{\text {th }}$ and $75^{\text {th }}$ percentile. Quantitative parameters were described by absolute and relative values and percent. The intergroup comparison was performed with Fisher's test. The difference between quantitative parameters was evaluated with Student's t-test.

RESULTS. "Index-PCI” clinical characteristics and risk factors are presented in Table 1. Angiographic characteristics and stents are described in Table 2. By the baseline data, the groups were comparable by the majority of clinical parameters. A higher rate of unstable angina was observed in the group with developed restenosis $(\mathrm{p}=0.05)$, as well as the tendency towards alcohol abuse ( $\mathrm{p}=0.07$ ). Initially, diabetes mellitus was observed more often in the group without restenosis than in the group with restenosis $(\mathrm{p}=0.06)$. By the angiographic data, the groups were comparable, except for a higher rate of the application of DES in the group without restenosis $(p=0.025)$. 
Table 1. "Index-PCI". Clinical data in groups with and without stenosis $(n=66)$.

\begin{tabular}{|c|c|c|c|}
\hline Parameters & $\begin{array}{l}\text { Group } 1(n=34) \\
\text { without } \\
\text { restenosis }\end{array}$ & $\begin{array}{l}\begin{array}{l}\text { Group } 2 \\
(\mathrm{n}=32)\end{array} \\
\text { with } \\
\text { restenosis }\end{array}$ & $\mathrm{p}$ \\
\hline Age (years) & $62.41 \pm 7.94$ & $61.94 \pm 9.76$ & 0.829 \\
\hline Sex (male) & $21(61.76 \%)$ & $24(75.00 \%)$ & 0.297 \\
\hline Arterial hypertension & $29(85.29 \%)$ & $30(93.75 \%)$ & 0.428 \\
\hline Dyslipidemia & $29(85.29 \%)$ & $27(84.38 \%)$ & 0.733 \\
\hline Obesity & $11(32.35 \%)$ & $9(28.13 \%)$ & 0.792 \\
\hline Type 2 diabetes mellitus & $10(29.41 \%)$ & $3(9.38 \%)$ & 0.062 \\
\hline Insulin dependence & $2(5.88 \%)$ & $1(3.13 \%)$ & 1.000 \\
\hline $\begin{array}{l}\text { Clinical worsening in patients with stable } \\
\text { ischemic heart disease }\end{array}$ & $30(88.24 \%)$ & $24(75.00 \%)$ & 0.210 \\
\hline MI in the anamnesis & $21(61.76 \%)$ & $23(71.88 \%)$ & 0.441 \\
\hline $\begin{array}{l}\text { Acute coronary syndrome, } \\
\text { including: }\end{array}$ & $4(11.76 \%)$ & $8(25.00 \%)$ & 0.210 \\
\hline acute myocardial infarction & $3(8.82 \%)$ & $3(9.38 \%)$ & 1.000 \\
\hline unstable angina & $1(2.94 \%)$ & $6(18.75 \%)$ & 0.051 \\
\hline CKD & $1(2.94 \%)$ & $0(0.00 \%)$ & 1.000 \\
\hline $\begin{array}{l}\text { Smoking } \\
\text { Smoked in past }\end{array}$ & $\begin{array}{l}8(34.78 \%) \\
6(24.00 \%)\end{array}$ & $\begin{array}{l}5(20.00 \%) \\
4(19.05 \%)\end{array}$ & 0.690 \\
\hline Alcohol abuse & $3(8.82 \%)$ & $7(21.88 \%)$ & 0.066 \\
\hline Familial cardiovascular diseases & $15(44.12 \%)$ & $14(43.75 \%)$ & 1.000 \\
\hline Physical inactivity & $4(11.76 \%)$ & $3(9.38 \%)$ & 1.000 \\
\hline Abdominal obesity & $3(8.82 \%)$ & $3(9.38 \%)$ & 1.000 \\
\hline EF LV, \% & $62.33 \pm 8.70$ & $60.43 \pm 6.27$ & 0.620 \\
\hline Weight, kg & $\begin{array}{l}79.00 \\
{[72.00 ; 100.00]}\end{array}$ & $\begin{array}{l}83.50 \\
{[78.00 ; 88.00]}\end{array}$ & 0.735 \\
\hline $\operatorname{BMI}\left(\mathrm{kg} / \mathrm{m}^{2}\right)$ & $\begin{array}{l}27.00 \\
{[25.90 ; 30.72]}\end{array}$ & $\begin{array}{l}27.44 \\
{[26.06 ; 30.85]}\end{array}$ & 0.895 \\
\hline
\end{tabular}

$\mathrm{EF}$ - ejection fraction; LV - left ventricle; median and its $25^{\text {th }}$ and $75^{\text {th }}$ percentile (Me [25;75])

Table 2. "Index-PCI". Angiographic data in groups with and without restenosis ( $n=66)$.

\begin{tabular}{|c|c|c|c|}
\hline Parameters & $\begin{array}{l}\text { Group } 1(n=34) \\
\text { without } \\
\text { restenosis }\end{array}$ & $\begin{array}{l}\text { Group 2 } \\
(\mathrm{n}=32) \\
\text { with } \\
\text { restenosis }\end{array}$ & $\mathrm{p}$ \\
\hline \multicolumn{3}{|l|}{ Variants of blood supply } & \multirow{4}{*}{0.188} \\
\hline \multirow{3}{*}{$\begin{array}{l}\text { Left } \\
\text { Right } \\
\text { Balanced }\end{array}$} & $4(11.76 \%)$ & $4(12.50 \%)$ & \\
\hline & $21(61.76 \%)$ & $25(78.13 \%)$ & \\
\hline & $9(26.47 \%)$ & $3(9.38 \%)$ & \\
\hline \multicolumn{3}{|c|}{$\begin{array}{l}\text { Classification of the damage of coronary } \\
\text { arteries by the effectiveness of intervention } \\
\text { (ACC/AHA) (potential success degree of } \\
\text { risk) }\end{array}$} & \multirow[t]{4}{*}{0.665} \\
\hline \multirow{3}{*}{$\begin{array}{l}\text { A (high/low) } \\
\text { B (moderate/moderate) } \\
\text { C (low/high) }\end{array}$} & $12(35.29 \%)$ & $8(25.00 \%)$ & \\
\hline & $13(38.24 \%)$ & $15(46.88 \%)$ & \\
\hline & $9(26.47 \%)$ & $9(28.13 \%)$ & \\
\hline
\end{tabular}




\begin{tabular}{|l|l|l|l|}
\hline $\begin{array}{l}\text { Reference arterial diameter in the place of } \\
\text { stenting, mm }\end{array}$ & $3.00[2.75 ; 3.50]$ & $3.00[3.00 ; 3.50]$ & 0.767 \\
\hline Bare Metal Stent (BMS) & $14(41.18 \%)$ & $21(65.63 \%)$ & 0.054 \\
\hline Drug-eluting stents (DES) & $18(52.94 \%)$ & $8(25.00 \%)$ & 0.025 \\
\hline BMS + DES & $2(5.88 \%)$ & $3(9.38 \%)$ & 0.668 \\
\hline PCI in two or more segments & $5(14.71 \%)$ & $12(37.50 \%)$ & 0.049 \\
\hline Residual stenosis in the stented vessel, \% & 15.00 & $\begin{array}{l}25.00 \\
{[5.00 ; 60.00]}\end{array}$ & 0.419 \\
\hline Dissection after PCI & {$[0.00 ; 50.00]$} & $0(0.00 \%)$ & 0.239 \\
\hline
\end{tabular}

ACC/AHA - American College Of Cardiologists/American Heart Association; median and it $25^{\text {th }}$ and $75^{\text {th }}$ percentile (Me $[25 ; 75])$

During "follow-up CAG/PCI", there was no significant difference by the duration of the observation between the groups. Diabetes mellitus significantly prevailed in Group I over Group II. The rate of ACS as the reason for hospitalization was higher in the group with restenosis than in the group without it (Table 3).

In Group II, the degree of restenosis was $80 \%$ with the prevalence of the diffuse process. Restenosis was primarily localized in the system of the left coronary artery (Table 4).

The progressing of native atherosclerosis outside the stent was performed in both groups with some prevalence in the group with restenosis (Table 5).

Table 3. "Follow-up CAG/PCI". Clinical data in groups with and without stenosis $(\mathrm{n}=66)$

\begin{tabular}{|c|c|c|c|}
\hline Parameters & $\begin{array}{l}\text { Group } 1(n=34) \\
\text { without } \\
\text { restenosis }\end{array}$ & $\begin{array}{l}\text { Group } 2 \\
(\mathrm{n}=32) \\
\text { with } \\
\text { restenosis }\end{array}$ & $\mathrm{p}$ \\
\hline Age (years) of "follow-up" & $63.41 \pm 8.32$ & $65.13 \pm 9.12$ & 0.428 \\
\hline Period of "follow-up", days & $\begin{array}{l}619.50 \\
{[418.00 ; 892.00]}\end{array}$ & $\begin{array}{l}655.00 \\
{[349.00 ; 928.50]}\end{array}$ & 0.865 \\
\hline Arterial hypertension & $32(94.12 \%)$ & $29(90.63 \%)$ & 0.668 \\
\hline Dislipidemia & $26(76.47 \%)$ & $29(90.63 \%)$ & 1.000 \\
\hline Type 2 diabetes mellitus & $13(38.24 \%)$ & $4(12.50 \%)$ & 0.024 \\
\hline Insulin-dependence & $2(5.88 \%)$ & $1(3.13 \%)$ & 1.000 \\
\hline $\begin{array}{l}\text { Clinical worsening in patients with stable ischemic } \\
\text { heart disease }\end{array}$ & $22(64.71 \%)$ & $24(75.00 \%)$ & 0.428 \\
\hline MI in the anamnesis & $1(2.94 \%)$ & $2(6.25 \%)$ & 0.608 \\
\hline $\begin{array}{l}\text { Acute coronary syndrome, } \\
\text { including: }\end{array}$ & $33(97.06 \%)$ & $23(71.88 \%)$ & 0.005 \\
\hline acute myocardial infarction & $1(2.94 \%)$ & $9(28.13 \%)$ & 0.005 \\
\hline unstable angina & $0(0.00 \%)$ & $3(9.38 \%)$ & 0.108 \\
\hline CKD & $1(2.94 \%)$ & $6(18.75 \%)$ & 0.051 \\
\hline Insulin-dependence & $3(8.82 \%)$ & $3(9.38 \%)$ & 1.000 \\
\hline
\end{tabular}


Table 4. "Follow-up CAG/PCI". Angiographic characteristics of restenosis (n=32)

\begin{tabular}{|c|c|}
\hline Parameters & Group II with restenosis \\
\hline Degree of restenosis in the place of stent grafting, $\%$ & $80[75 ; 99]$ \\
\hline \multicolumn{2}{|l|}{ Type of } \\
\hline restenosis & $11(34.38 \%)$ \\
\hline & $19(59.38 \%)$ \\
\hline \multicolumn{2}{|l|}{ Diffuse } \\
\hline Multifocal & $2(6.25 \%)$ \\
\hline \multicolumn{2}{|l|}{ Arteria with restenosis } \\
\hline \multirow{3}{*}{$\begin{array}{l}\text { Anterior interventricular branch } \\
\text { Circumflex branch } \\
\text { Right coronary artery }\end{array}$} & $13(40.63 \%)$ \\
\hline & $13(40.63 \%)$ \\
\hline & $6(18.75 \%)$ \\
\hline
\end{tabular}

median and its 25 th and 75 th percentile (Me [25;75])

Table 5. "Follow-up CAG/PCI". Angiographic data in the group of patients with and without restenosis $(n=66)$

\begin{tabular}{|l|l|l|l|}
\hline Parameters & $\begin{array}{l}\text { Group 1 (n=34) } \\
\text { without } \\
\text { restenosis }\end{array}$ & $\begin{array}{l}\text { Group 2 } \\
(\mathrm{n}=32) \\
\text { with } \\
\text { restenosis }\end{array}$ & $\mathrm{p}$ \\
\hline Progressing of native coronary atherosclerosis & $13(38.24 \%)$ & $18(56.25 \%)$ & 0.167 \\
\hline Intracoronary blood clot & $1(2.94 \%)$ & $3(9.38 \%)$ & 1.000 \\
\hline
\end{tabular}

The rate of repeated PCI during "follow-up" was significantly higher in the group with restenosis than in the group without restenosis ( $71 \%$ and $97 \%$, respectively, $\mathrm{p}=0.006)$.

By the parameters of the lipid spectrum, there was no significant difference between Groups I and II in "index-PCI". The level of glucose was higher in Group I than Group II (Me 5.8 [5.1;6.8] and Me 5.3 [5.0;5.9], respectively, $\mathrm{p}=0.053$ ) (Table 6).

During the observation ("index PCI" - "follow-up CAG/PCI"), the mean parameters in groups decreased in the level of TCH, LDL-C, Very Low-Density Lipoprotein Cholesterol (VLDLC), HDL-C, and TG.

The intergroup comparison of "follow-up CAG/PCI" showed that the level of TCH was higher in Group I (Me 4.7 [4.3;5.7]) than in Group II (Me 4.5 [3.9;5.0]) (p=0.051), the level of nonHDL-C was significantly higher in Group I than in Group II (Me 3.6 [3.1;4.7] and Me 3.3 [2.8;3.8], respectively, $\mathrm{p}=0.033$ ). By the parameters HDL-C, TG, creatinine, and glucose, the parameters of the groups were comparable.

Table 6. Dynamic parameters of lipid spectrum and main biochemical markers in groups of patients with and without restenosis during "index-PCI" and "follow-up CAG/PCI". 


\begin{tabular}{|c|c|c|c|c|c|c|c|c|}
\hline & $\begin{array}{l}\text { Group I } \\
\text { without } \\
\text { restenosis } \\
\text { index }(n=34)\end{array}$ & $\begin{array}{l}\text { Group II } \\
\text { with } \\
\text { restenosis } \\
\text { index }(n=32)\end{array}$ & $\begin{array}{l}\mathrm{p} \\
\text { index }\end{array}$ & $\begin{array}{l}\text { Group } 1 \\
\text { without } \\
\text { restenosis } \\
\text { follow-up } \\
(\mathrm{n}=34)\end{array}$ & $\begin{array}{l}\text { Group II } \\
\text { with } \\
\text { restenosis } \\
\text { follow-up } \\
(\mathrm{n}=32)\end{array}$ & $\begin{array}{l}\mathrm{p} \\
\text { follo } \\
\text { w-up }\end{array}$ & $\begin{array}{l}\text { Delta } \\
\text { group 1 } \\
\text { without } \\
\text { restenosis }\end{array}$ & $\begin{array}{l}\text { Delta group } \\
2 \text { with } \\
\text { restenosis }\end{array}$ \\
\hline $\begin{array}{l}\mathrm{TCH}, \\
\mathrm{mmol} / \mathrm{L}\end{array}$ & $\begin{array}{l}5.30 \\
{[4.60 ; 6.80]} \\
\end{array}$ & $\begin{array}{l}5.10 \\
{[3.75 ; 6.30]} \\
\end{array}$ & 0.210 & $\begin{array}{l}4.70 \\
{[4.25 ; 5.65]}\end{array}$ & $\begin{array}{l}4.50 \\
{[3.90 ; 5.00]}\end{array}$ & 0.051 & $\begin{array}{l}-0.60(- \\
11.32 \%) \\
\end{array}$ & $\begin{array}{l}-0.60(- \\
12.24 \%) \\
\end{array}$ \\
\hline $\begin{array}{l}\mathrm{LDL}-\mathrm{C}, \\
\mathrm{mmol} / \mathrm{L}\end{array}$ & $\begin{array}{l}2.96 \\
{[2.46 ; 4.14]}\end{array}$ & $\begin{array}{l}3.08 \\
{[2.21 ; 3.83]}\end{array}$ & 0.659 & $\begin{array}{l}2.84 \\
{[2.47 ; 4.05]}\end{array}$ & $\begin{array}{l}2.58 \\
{[2.09 ; 3.11]}\end{array}$ & 0.082 & $\begin{array}{l}-0.12(- \\
3.59 \%)\end{array}$ & $\begin{array}{l}-0.39(- \\
12.70 \%)\end{array}$ \\
\hline $\begin{array}{l}\text { VLDL-C, } \\
\mathrm{mmol} / \mathrm{L}\end{array}$ & $\begin{array}{l}0.70 \\
{[0.49 ; 0.90]}\end{array}$ & $\begin{array}{l}0.68 \\
{[0.56 ; 1.11]}\end{array}$ & 0.970 & $\begin{array}{l}0.68 \\
{[0.50 ; 0.90]}\end{array}$ & $\begin{array}{l}0.67 \\
{[0.50 ; 0.88]} \\
\end{array}$ & 0.817 & $\begin{array}{l}-0.02(- \\
2.13 \%) \\
\end{array}$ & $\begin{array}{l}-0.01(- \\
1.28 \%) \\
\end{array}$ \\
\hline $\begin{array}{l}\text { HDL-C, } \\
\mathrm{mmol} / \mathrm{L}\end{array}$ & $\begin{array}{l}1.20 \\
{[0.97 ; 1.39]}\end{array}$ & $\begin{array}{l}1.07 \\
{[0.87 ; 1.37]}\end{array}$ & 0.240 & $\begin{array}{l}1.08 \\
{[0.88 ; 1.26]}\end{array}$ & $\begin{array}{l}1.19 \\
{[0.88 ; 1.26]}\end{array}$ & 0.645 & $\begin{array}{l}-0.12(- \\
12.12 \%)\end{array}$ & $\begin{array}{l}0.12 \\
(12.12 \%)\end{array}$ \\
\hline $\begin{array}{l}\text { Non-HDL-C, } \\
\mathrm{Mmol} / \mathrm{L}\end{array}$ & $\begin{array}{l}4.00 \\
{[3.16 ; 5.39]}\end{array}$ & $\begin{array}{l}3.82 \\
{[2.59 ; 5.09]}\end{array}$ & 0.121 & $\begin{array}{l}3.57 \\
{[3.09 ; 4.71]}\end{array}$ & $\begin{array}{l}3.32 \\
{[2.78 ; 3.80]}\end{array}$ & 0.033 & $\begin{array}{l}-0.43(- \\
9.93 \%)\end{array}$ & $\begin{array}{l}-0.50(- \\
12.85 \%)\end{array}$ \\
\hline $\mathrm{TG}, \mathrm{mmol} / \mathrm{L}$ & $\begin{array}{l}1.57 \\
{[1.07 ; 2.37]}\end{array}$ & $\begin{array}{l}1.55 \\
{[1.21 ; 2.42]}\end{array}$ & 0.476 & $\begin{array}{l}1.48 \\
{[1.09 ; 1.98]}\end{array}$ & $\begin{array}{l}1.44 \\
{[0.97 ; 2.04]}\end{array}$ & 0.775 & $\begin{array}{l}-0.09(- \\
4.52 \%)\end{array}$ & $\begin{array}{l}-0.11(- \\
6.51 \%)\end{array}$ \\
\hline $\begin{array}{l}\text { Creatinine, } \\
\mu \mathrm{mol} / \mathrm{L}\end{array}$ & $\begin{array}{l}99.00 \\
{[84.00 ; 107.0} \\
0]\end{array}$ & $\begin{array}{l}94.50 \\
{[84.50 ; 101.5} \\
0]\end{array}$ & 0.985 & $\begin{array}{l}94.00 \\
{[85.00 ; 102.00]}\end{array}$ & $\begin{array}{l}90.50 \\
{[78.00 ; 109.00]}\end{array}$ & 0.377 & $\begin{array}{l}-5.00(- \\
4.92 \%)\end{array}$ & $\begin{array}{l}-4.00(- \\
4.17 \%)\end{array}$ \\
\hline
\end{tabular}

median and its 25 th and 75 th percentile (Me [25;75])

A higher level of LDL-C was observed in Group I in comparison with Group II (Me 2.8 [2.5;4.1] and Me 2.6 [2.1;3.1], respectively, $\mathrm{p}=0.082$ ).

The detailed distribution of the parameters LDL-C depending on the recommended target values is presented in Table 7. LDL-C lower than $1.8 \mathrm{mmol} / \mathrm{L}$ was observed more often in patients with clinical worsening in a remote period (groups with late complications in patients with and without stenosis: $13.9 \%$ and $15 \%$, respectively) than in the early period (Groups I and II: $4.4 \%$ and $4.0 \%$, respectively). There were no differences between the groups with and without restenosis in the stent in patients with the level of LDL-C lower than $1.8 \mathrm{mmol} / \mathrm{L}$. The parameter values lower than $1.5 \mathrm{mmol} / \mathrm{L}$ were quite rare. In all the groups, regardless of the period of observation and the presence of stenosis in the stent, the parameter values higher than $2.6 \mathrm{mmol} / \mathrm{L}$ prevailed.

Table 7. Target levels of lipid parameters at the stage of "follow-up CAG/PCI"

\begin{tabular}{|l|l|l|l|}
\hline Parameters & $\begin{array}{l}\text { Late } \\
\text { complication } \\
\text { without } \\
\text { restenosis } \\
(\mathrm{n}=34)\end{array}$ & $\begin{array}{l}\text { Late } \\
\text { complications } \\
\text { with } \\
\text { restenosis } \\
(\mathrm{n}=32)\end{array}$ & $\mathrm{p}$ \\
\hline TCH $<4 \mathrm{mmol} / \mathrm{L}$ & $5(14.71 \%)$ & $8(25.00 \%)$ & 0.540 \\
\hline non-HDL-C <2.59 mmol/L & $3(8.82 \%)$ & $6(18.75 \%)$ & 0.477 \\
\hline $\begin{array}{l}\text { LDL-C }<1.8 \mathrm{mmol} / \mathrm{L} \text { or a } 50 \% \text { decrease from } \\
\text { baseline values } 1.8-3.5 \mathrm{mmol} / \mathrm{L}\end{array}$ & $1(2.94 \%)$ & $2(6.25 \%)$ & 1.000 \\
\hline TG $<1.7 \mathrm{mmol} / \mathrm{L}$ & $17(50.00 \%)$ & $21(65.63 \%)$ & 0.582 \\
\hline
\end{tabular}

During the past years, in the publications, the term "neoatherosclerosis" is defined as a development of restenosis after the stenting of coronary arteries that is similar to traditional 
atherosclerosis by such serious clinical complications as an acute coronary syndrome and, in some cases, thrombosis of coronary arteries [3]. Visual pictures obtained during intracoronary ultrasound imaging, especially, during optic coherent tomography, and accumulated morphological data allow the specialists to differentiate fibromuscular proliferation, typical for early restenosis, and neoatherosclerosis [5]. Neoatherosclerosis is characterized by the formation of lipid plaques with the elements of capsule damage and thrombosing. The pathogenesis of atherosclerosis includes the most important element - lipid alterations, which are confirmed by a prognostic significance of cholesterol metabolism and the expected effectiveness of hypolipidemic therapy, including statins [6]. This factor can also affect the formation of neoatherosclerosis in the stent that develops at the later stages after PCI.

In the present study, patients were treated as a group of very high and extreme risk by the clinical characteristics and damage of coronary arteries. In the initial phase of "index PCI", the majority of patients had high and moderate levels of LDL-C and there were no differences by these parameters between the groups. During the remote repeated examination, lipid characteristics improved in the groups with and without restenosis, including a decrease in LDL-C, which was insufficient for the target levels despite strict dietary recommendations and statin therapy. At the final stage of "follow-up", the lack of a significant difference by the lipid parameters between the groups with and without restenosis in the stents did not provide grounds for the casual role of lipids in the development of neoatherosclerosis in patients with late restenosis.

There are also other factors of atherosclerotic progressing in the development of restenosis [7]. The influence of an increased level of genetically determined lipoprotein was observed [8] and the involvement of inflammatory and immune factors, the significance of which was confirmed by the effectiveness of anti-inflammatory therapy [9]. New factors were revealed that influenced the accelerated development of atherosclerosis in the drug-eluting stents, in particular, perilipin 2 [10].

CONCLUSIONS. In the remote period after PCI, the level of lipids in blood did not reach the target level and their values were worse in the group without restenosis than with restenosis. The development of natural atherosclerosis remains the dominating factor of clinical worsening at the remote period after the stenting of coronary arteries.

\section{FINANCIAL SUPPORT AND SPONSORSHIP}

Nil.

\section{CONFLICTS OF INTEREST}

The authors declare no conflict of interest

SUPPLEMENTARY DATA (DOI).

\section{REFERENCES}

1. Habara S., Kadota K., Kuwayama A. et al. Circulation: Cardiovascular Interventions, 2016, vol. 9, no. 

07.07.2019). doi: 10.1161/circinterventions.116.004449.

2. Mazaev V.P., Komkov A.A., Riazanova S.V. Long-term in-stent restenosis development in coronary arteries after percutaneous coronary interventions with bare metal and drug-eluting stents implantation depending on clinical data and risk factors [Razvitie restenozov $\mathrm{v}$ koronarnykh arteriiakh na pozdnikh srokakh posle chreskozhnykh koronarnykh vmeshatel'stv pri implantatsii golometallicheskikh ili pokrytykh lekarstvom stentov $\mathrm{v}$ zavisimosti ot klinicheskikh dannykh i faktorov riska]. Modern problems of science and education- Sovremennye problemy nauki $i$ obrazovaniia, 2017, no. 4. Available at: http://www.science-education.ru/ru/article/view?id=26645 (accessed 07.07.2019), doi: 10.17513/spno.26645

3. Komkov A.A., Mazaev V.P., Riazanova S.V. Neoatherosclerosis in the stent [Neoateroskleroz v stente]. Rational Pharmacotherapy in Cardiology - Ratsional'naia Farmakoterapiia v Kardiologii, 2015, vol. 6, no. 11, pp. 626-633. doi: 10.20996/1819-6446-2015-11-6-626-633.

4. Belloni F., Fracassi F., Sgueglia G. et al. Early and late restenosis of drug-eluting stents: an observational study about predictors, clinical presentation and response to treatment (the LATE DES study). Asia Intervention. 2017, Vol. 3, pp. 131-138, doi 10.4244/AIJ-D-16-00021.

5. Sabbah M., Kadota K., El-Eraky A. et al. Comparison of in-stent neoatherosclerosis and tissue characteristics between early and late in-stent restenosis in second-generation drug-eluting stents: an optical coherence tomography study. The International Journal of Cardiovascular Imaging, 2017, vol. 33, no 10, pp. 1463-1472, doi: 10.1007/s10554-017-1146-7.

6. Lee S.Y., Hur S.H., Lee S.G. et al. Optical coherence tomographic observation of in-stent neoatherosclerosis in lesions with more than $50 \%$ neointimal area stenosis after second-generation drug-eluting stent implantation. Circulation: Cardiovascular Interventions, 2015, vol 8, no 2. Available at: https://www.ahajournals.org/doi/10.1161/CIRCINTERVENTIONS.114.001878 (accessed 07.07.2019), doi 10.1161/CIRCINTERVENTIONS.114.001878.

7. Mazaev V.P., Komkov A.A., Riazanova S.V. Clinical condition and cardiovascular risk factors displaying neoatherosclerosis in stented coronary arteries with developing restenosis [Klinicheskoe sostoianie i faktory serdechno-sosudistogo riska kak otrazhenie neoateroskleroza v stentirovannykh koronarnykh arteriiakh pri pozdnem razvitii restenozov]. Cardiovascular Therapy and Prevention Kardiovaskuliarnaia terapiia i profilaktika, 2016, vol. 15, no 5, pp. 64-69, doi 10.15829/17288800-2016-5-64-69.

8. Willeit P., Ridker P.M., Nestel P.J. et al. Baseline and on-statin treatment lipoprotein(a) levels for prediction of cardiovascular events: individual patient-data meta-analysis of statin outcome trials. The Lancet, 2018, Vol. 392, pp. 1311-1320, doi 10.1016/S0140-6736(18)31652-0.

9. Ridker P.M., Libby P., MacFadyen J.G. at al. Modulation of the interleukin-6 signalling pathway and incidence rates of atherosclerotic events and all-cause mortality: analyses from the Canakinumab AntiInflammatory Thrombosis Outcomes Study (CANTOS). European Heart Journal, 2018, Vol. 39, no 38, pp. 
3499-3507, doi 10.1093/eurheartj/ehy310.

10. Niccoli G., D'Amario D., Borovac J.A. et al. Perilipin 2 levels are increased in patients with in-stent neoatherosclerosis: A clue to mechanisms of accelerated plaque formation after drug-eluting stent implantation. International Journal of Cardiology, 2018, vol. 258, no 1, pp. 55-58, doi: 10.1016/j.ijcard.2018.01.074. 